\title{
Translating Wealth in a Globalised Extractivist Economy: Contrabandistas and Accumulation by Diversion
}

\author{
Cecilie Vindal Ødegaard
}

The discourse of extractivism in Peru appears to offer a modernist vision of citizenship and progress accessible to all, and is presented by political leaders as key to economic growth and poverty reduction. Meanwhile, faced with recurrent conflicts and protests (de la Cadena 2010; Li 2015), Peruvian authorities have difficulties in legitimising their extractive politics. In Peru as elsewhere, fossil fuels have become an important site for sovereign contention (Mitchell 2011), and the transnationalised, capital-intensive extraction and distribution of fossil fuels are subject to degrees of regulation and control beyond any other commodity. Yet, as this chapter reveals, there are sites and moments of informalisation where the materialities of fuels and their attendant wealth are redirected and reconfigured.

Despite great interest in extractive conflict in South America in recent years, relatively few studies have focused on the tactics used by local groups and communities to mediate and redirect the forces of the state's extractive

\footnotetext{
C. Vindal Ødegaard $(\bowtie)$

University of Bergen, Bergen, Norway

e-mail: cecilie.odegaard@uib.no
}

(C) The Author(s) 2019

C. Vindal Ødegaard, J. J. Rivera Andía (eds.), Indigenous Life

Projects and Extractivism, Approaches to Social Inequality and

Difference, https://doi.org/10.1007/978-3-319-93435-8_5 
politics and the associated benefits. Most studies tend to focus primarily on groups and communities that unambiguously oppose the state's enforcement of extractive capitalism. In this chapter, I explore countermovements which challenge the extractivist state in ways that are more ambiguous and do not fit neat dichotomies of modern-indigenous, capitalist-traditional, accommodation-resistance. I discuss the smuggling of fuels from Bolivia to Peru, which became widespread after the Bolivian government's nationalisation of oil and gas in 2006 and the subsidisation of Bolivian energy prices. In so doing, I describe attempts to redirect the official distribution of fossil fuels and examine how contrabandistas seek to subsume fossil wealth to other modes of sociality as they redistribute profit by sharing and making investments in kin, colleagues, and earth-beings. ${ }^{1}$ In this and other ways, contrabandistas contribute towards the re-creation of local forms of relatedness in a manner that is closely entangled with extralocal, global commodities and aimed at the translation and integration of extralocal value. I argue that the contrabandistas' redirections of commodities from official circuits are part of life-making projects that partly differ from yet are partly complicit in hegemonic discourses on resource extraction and progress, and can be seen to entail a kind of translation from one form of value accumulation to another. In this manner, and drawing inspiration from Tsing's (2015) notion of translation between capitalist forms of accumulation and other economic forms, I seek to address the complexities of contemporary life in the context of extractivism in the Andes.

My observations and arguments are based on several periods of fieldwork in Peru since 1997, building mainly on work in 2007, 2011, and 2016. I worked on the Peruvian side of the border, with vendors and contrabandistas who carry merchandise between Peru and Bolivia, some of whom are based in Arequipa (where I conducted most of my fieldwork) and others who live in rural communities closer to the Bolivian border. Arequipa is an important regional distribution point for trade between the highland and the coast, as well as for merchandise brought into Peru from Bolivia and Chile. People come to Arequipa from as far away as Lima to buy contraband goods for further sale in the capital (see also Tassi et al. 2013). Central to my fieldwork, especially in 2011 and 2016, was following those of my interlocutors ${ }^{2}$ who work as contrabandistas connected to one of the outdoor markets in Arequipa, Mercado Nuevo. This market association has around 1500 members, many of whom are bilingual Spanish and Aymara, or Quechua speakers. The contrabandistas travel every week to collect merchandise and are important suppliers of goods to 
vendors and retailers at Mercado Nuevo; some have their own market pitches there. The contrabandistas are mostly migrants to Arequipa from communities in the Andean highlands and are generally but not exclusively women. While I cannot explore fully here the many reasons that women are in the majority in trade and contraband, a central dimension in this specific context is the notion that women manage money and economic matters while men manage politics (Harris 2000). There are long traditions in the Andes for women's involvement in barter and trade, so trading is not necessarily something first learned in the city. In many ways, the contrabandistas represent a kind of social banditry (Hobsbawm 1969) that redistributes wealth beyond the reach of state and extractive companies; their claims to earn a living hold for many a certain legitimacy, particularly in light of the state's extractivist policies of recent years. While contrabandistas rely on the flow of global commodities, I argue that they convert and translate these flows in and through practices that are embedded and implicated in local sociospatial relations. By convert and translate I mean to suggest that contrabandistas not only convert the flow of wealth to another circuit and form but also translate such flows from one system of relationships and meaning to another. My focus on the redirection and possible translation of fossil wealth is not intended to underplay, however, the issue of wealth accumulation and inequality in the extractive state. Rather, central to my argument is the view that smuggling has emerged from structures of inequality, both historically and in view of contemporary extractive politics in Peru, and that the contrabandistas exemplify some of the attempts made to mediate and redirect the forces of these politics. This, I argue, involves not only commodity flows but also the cultural, cosmological, and relational aspects, or logics, of mediation. $\mathrm{My}$ intention is not to romanticise a practice such as the smuggling of fuel, but, rather, to explore these practices from the perspective of the contrabandistas involved and, especially, to understand the relations through which such practices are realised.

The smuggling of fuels across the borders from Bolivia became particularly widespread after the Bolivian government's nationalisation of oil and gas in 2006 and the subsidisation of energy prices for the domestic market. Subsidisation lowered price levels in Bolivia below those of neighbouring countries, such as Peru, ${ }^{3}$ resulting in the illegal export of fuels from Bolivia (see also Montesinos 2011). In December 2010, the issue of illegal exports led the Bolivian government to remove subsidies, causing prices to almost double. People in Bolivia then protested, refusing to pay bus fares. After 
three days, the protests led to a reduction in prices — and the smuggling of fuels continued. In Peru, fuel smuggled from Bolivia is used primarily for ordinary consumption and in informal mining. ${ }^{4}$ Many of my interlocutors in Arequipa, especially the contrabandistas, justified the smuggling of fuel from Bolivia in the context of Peruvian energy politics. They cited the higher energy prices in Peru, arguing that Peruvian energy resources are also being exported. A typical response comes from one of my interlocutors: '[We get fuel in Bolivia], since it is cheaper [there]. We [Peruvians] also have gas, but we export it to other countries, at cheaper prices even, while we [ordinary citizens] have to pay a lot.'

Before going into the practices of smuggling, I discuss energy prices and price-setting mechanisms in Peru in recent years as relevant not only to popular protests in the country but also to the way in which contrabandistas legitimise their actions. Academic debates about extractivist conflicts tend to give less attention to the question of energy prices, in Peru and elsewhere, perhaps because concerns with domestic energy prices may have an undertone of populist political rhetoric and resource nationalism in many situations. In the context of this chapter, however, energy prices create an important backdrop for understanding both the global capitalist creation of fossil fuels as a commodity construct as well as the sense of unfairness that permeates contrabandistas' experiences of the state's extractive politics. Indeed, energy prices, exportation, and globalised price mechanisms represent a general concern especially among the urban poor-often Quechua- or Aymara-speaking migrants—with whom this chapter is concerned.

\section{Energy Politics, and Protests}

The idea that natural resource extraction will lead to economic growth and development for all is, as noted, prevalent in official discourse in Peru (see also Li 2015). Nowadays, it represents a model currently supported by state-corporate partnership and a liberal line with respect to foreign investment in the extractive sector. The extraction of oil in the country first started in 1971 with PetroPeru. ${ }^{5}$ During Alberto Fujimori's presidency in the 1990s, PetroPeru was privatised and economic policies increasingly liberalised, opening up for foreign investment in the energy sector. While the state still controls most downstream production, pipelines, and refineries, Argentina's Pluspetrol controls over half of the production of crude oil. Peru's major natural gas field, Lote 88, was opened in 2004 in the 
department of Cusco under the management of the state-corporate company Camisea. The Camisea fields are Peru's top energy source, producing 1.6 billion cubic feet of natural gas per day. Just under half of the production is sold in the domestic market at regulated prices and used mostly to generate electricity; some is allocated for industrial use in mining, for example, and a small percentage is sold to consumers for residential use and as motor fuel (Ødegaard 2015). When Camisea started producing in 2004, gas and electricity prices for Peruvian consumers were relatively low compared to neighbouring countries. Prices soon rose, however, as the royalties Peru earns from Camisea's exports fell sharply in competition with cheap gas from US shale producers.

During preparations for extracting gas in the Camisea area in the 1990s, the authorities failed at first to attract enough investment for the project. The political landscape was considered risky because of the 'dirty war' between the guerrilla movement Shining Path and military forces, and Peru's status as one of the region's poorest consumer bases. Foreign investments were further compromised by Fujimori's insistence on keeping natural gas for the domestic market, leading Shell to withdraw from the project. By the time Fujimori's government fell in 2000, Peru's economic leaders considered that they had to offer a favourable export option to attract investment by international companies. Pedro Pablo Kuczynski, who served as finance minister and later as prime minister in the Alejandro Toledo administration at the time, helped pass two pieces of legislation which allowed firms to export the gas from the smaller block 56, while fixing the price of gas from the larger block 88 for the domestic market. In 2007, the Spanish firm Repsol, which forms part of the Camisea consortium, obtained the rights to export gas from the Camisea fields. The same year Repsol signed a 15-year contract to export 70 per cent of the gas to Mexico's state electric utility, which pegs prices to the US benchmark, Henry Hub. ${ }^{6}$ Over the next five years, US shale producers drove the Henry Hub price down by more than half, taking Peru's royalties with it due to a progressive royalty scheme tying royalties to prices in the contracts signed by Toledo's government. Consequently, cheap gas in the United States contributed to lowering the price of Camisea gas committed to Mexico until 2023 , and the price ceiling on natural gas sold on the domestic market was lifted. Most political sides have later called for renegotiations of the Camisea contracts to extract higher royalties. In several protests, people have opposed the increased domestic prices of gas and electricity as well as the exportation of Camisea's natural gas (Ødegaard 2015). Protesters 
have also condemned previous governments for not connecting the gas fields with Peru's southern cities, including Cusco, the provincial capital of the state where the gas is extracted. In an attempt to amend the situation, then president Kuczynski (2016-2018) called for the extraction of more natural gas from the Camisea consortium via exploitation of new fields and expansion of the infrastructure needed to transport the gas from Cusco to other cities.

While protests against the extractive industries in Peru in recent years have been spurred primarily by social and environmental effects in the communities most immediately affected, the protests related to increased exportation and domestic energy prices are aspects of Peru's extractive politics most often criticised by the urban poor, including Quechua- and Aymara-speaking migrants. In Arequipa, energy prices, especially the price of gas, have been a continual concern for many. Several protests have been organised in the city; during my fieldwork of January 2011, hundreds of people marched to Plaza de Armas in Arequipa from the shantytowns protesting the rising price of gas. ${ }^{7}$ Similar protests followed in Cusco, Puno, and Tacna. ${ }^{8}$ In support of the demonstrators, the bus companies stopped running busses. During the protests, one of my interlocutors in the shantytown where I have lived during my fieldwork sessions said: 'This is a serious problem and therefore people protest; when the gas prices rise, the prices of everything else rise along with it. Transport, food, water: everything becomes more expensive, because everything moves with combustible [fuels].' Prices generally are interdependent with the price of gas, but fuel is also considered a source of mobility both literally (i.e., for transport) and socially (i.e., associated with a certain level of consumption and living conditions). Similar protests against energy prices have continued. In March 2016, for instance, there was one week of paralysing protest in the department of Ucayali over the increased cost of electricity, in which several peasant indigenous groups joined in, demanding additional reductions in the prices of water, cooking gas, and telephone services ${ }^{9}$ ( $\mathrm{La}$ República 2016).

While these and similar protests have focused specifically on energy prices, they reflect an attempt to contest the unequal distribution of wealth in a country considered rich with natural resources. They are a critique of the Peruvian government's accommodation of the interests of multinational companies, contesting the terms by which governments have developed extractive politics in the country. The people who protest represent a variety of different positions and perspectives in society: farmers and 
landowners, indigenous groups and urban consumers. While extractive conflicts in Peru are often envisioned as involving primarily rural indigenous groups, we should be careful not to rely on an understanding of such conflicts as an 'indigenous' issue, as this could serve to downplay the more wide-reaching issues raised by indigenous protesters. We should also be wary of potential dilemmas of an essentialised understanding of 'indigeneity' in extractive conflicts. Such dilemmas, as argued by Fabricant (2013) in the Bolivian context, are related, for example, to what an essentialised notion of indigeneity may mean for the large numbers of Quechua- and Aymara-speaking migrants who may not necessarily oppose resource extraction as such, and may even benefit from it, but may be contesting the general terms by which it is conducted.

Despite conflicts over the transnationalised price-setting mechanisms in Peru in recent years, there are a variety of ways in which inhabitants may try to 'localise' such global commodities and sometimes benefit directly from the extractive industries. In Peru, some inhabitants have anticipated business opportunities around extractive sites and along pipeline building routes. One such site is the new port constructed in Ica at the receiving end of a new pipeline from the Camisea fields. Already years before the pipeline was to be completed, migrants (often from peasant communities in the highlands) started arriving in the area around the port construction site and informally occupying land for housing and businesses in hopes that the new pipeline would bring economic opportunities. Another widespread practice in Peru is the initiation of informal mining projects, which often cause further damage to local communities and ecosystems through deforestation and pollution. The smuggling of fuel, which I discuss in more detail below, is another way to attempt to benefit from extractivist projects-one also taking place at the margins of the formal economy. In more ways than one, however, contrabandistas are the kinds of actors who are often left out of our analytical conversations, perhaps because it is not clear how we can understand their role in relation to globalised capitalism, nor how they contribute to an alternative 'politics of nature'. On the one hand, contrabandistas may appear as 'perfect neoliberal citizens', accommodating their own quest for a good life to growing demands of flow and consumption. On the other hand, they draw on a different mode of sociality (including the powerful earth-beings) in their ways of distributing commodities and understanding wealth. The contrabandistas may therefore appear to provide us with analytical plunder, bringing to mind questions about the nature of capitalism, and the (im)possibility of a space outside of capitalism's empire 
(e.g., Hardt and Negri 2000), or the potential for a coexistence with other forms of sociality and economic life (Tsing 2015).

Through perspectives that insist on the unity and homogeneity of the system, scholars often criticise capitalism for concentrating wealth through historically changing processes and technologies for extracting and accumulating value. This emphasis on the uniformity of capitalism and its hold on the world is also often considered essential for building a critical political position and for conceptualising possibilities to transcend capitalism, that is, through the envisioning of alternative forms of solidarity (Tsing 2015: 66). In seeking to understand the workings of capitalism, however, Tsing argues that we need to recognise the existence of economic diversity and explore the ways in which other economic forms can be found in the midst of capitalist worlds. Rather than discussing such forms primarily as alternatives to capitalism (see, e.g., Gibson-Graham 2006), Tsing suggests we pay attention to the elements and activities, both human and nonhuman, which are integrated into global supply chains and accommodate capitalist accumulation, despite existing outside official systems of control. Tsing (2015: 63) calls such forms the 'pericapitalist mode', referring to activities accommodated to a capitalist value system through different forms of conversion and translation. For instance, the pericapitalist mode may refer to the process through which lead firms can amass capital without controlling the conditions under which commodities are produced (also termed salvage accumulation). Pericapitalist economic forms, Tsing argues, can even be important sites for rethinking the authority of capitalism in our lives: 'To understand capitalism (and not just its alternatives), then, we can't stay inside the logics of capitalists; we need an ethnographic eye to see the economic diversity through which accumulation is possible' (ibid.: 66). This chapter focuses on a somewhat different phenomenon, by exploring commodity flows and forms of wealth distribution that take place outside the reach of both the state and lead firms and raising the following questions: What characterises the activities of contrabandistas visà-vis global commodity chains? What forms of conversion and translation are the contrabandistas involved in? My focus on translation draws upon, but also elaborates further upon, Tsing's notion of translation through the pericapitalist mode. More generally, it draws inspiration from a wellestablished body of scholarship emerging especially from feminist anthropology, having shown that class formation is cultural formation, and having pioneered the study of transactions across heterogeneous economic landscapes (see, e.g., Yanagisako 2002; Harris 2000; Ong 2006). I draw 
on the term translation precisely to capture the way that acts of conversion and translation in global capitalism may take place across varied social, cultural, and political spaces. According to Tsing, translations across sites of difference are capitalism in that they enable investors to accumulate wealth. Translation, in this sense, is the drawing of one world- and lifemaking project into another, which is often, although not always, facilitated by the capitalist system of commensuration (Tsing 2015: 62). To work with a notion of translation in this wider sense is interesting because, while it may draw attention to language, it can also refer to other forms of partial accommodations, or partial connections (Strathern 2004).

\section{The Smuggling of Fuels}

Those who bring in contraband generally self-identify as contrabandistasproudly so. They are viewed as important suppliers of merchandise, constantly travelling long distances to bring goods to market vendors. As I have discussed elsewhere $(2008,2016)$, contrabandistas often criticise official interferences as immoral and illegitimate, questioning the right of the officials to interfere in people's efforts to make a living. The legal assessor of the Chamber of Commerce and Industry in Arequipa estimated that almost 90 per cent of the inhabitants in border areas are involved in contrabando and provide consumer goods to the entire country: 'It is difficult to do anything, because people get angry, and will ask for an alternative-something which does not exist.' ${ }^{10}$ As mentioned, contrabandistas may be considered as practitioners of a kind of social banditry (Hobsbawm 1969), as their claims for the right to earn a living hold a certain legitimacy. Their claims are informed by historical structural inequalities and by the recognition that there are no other jobs to get anyway, an assertion typical of many contrabandistas. From an official perspective though, fuels are not 'just another commodity': Fuels are capital-intensive rather than labour-intensive, demanding advanced technology and infrastructure. The extraction and distribution of oil and natural gas are highly institutionalised, corresponding with the high demand in the global market for these commodities. In this regard, the illegal export of fuels not only represents economic loss ${ }^{11}$ for countries such as Bolivia where energy prices are subsidised, but also raises questions of national borders and state sovereignty. Fuel smuggling (as well as the facilitating bribes) in effect contests state-corporate interests and investment; it entails denials both of state legitimacy in the control of commodity flows and of territorial boundaries themselves, and further exposes 
the extractivist state's problem of legitimatising its energy politics. Through smuggling, fuels are made into petty commodities, de-institutionalised and informalised, amounting to a challenge to sovereign investment in fuel extraction and distribution. As I have examined elsewhere (2016), measures to reduce smuggling have been introduced on both sides of the borderparticularly in Bolivia where the government has targeted border control measures especially with regards to fuel smuggling.

People from both the Peruvian and Bolivian side of the border are involved in the trafficking of fuel (petrol, diesel). They often buy fuel at petrol stations in Bolivia with the purpose of selling it in Peru. Some contrabandistas, especially the women, transport fuel across the border by foot or bicycle trolley, while others hide it on the roofs of buses amidst luggage. The drivers involved in fuel smuggling are generally men who combine their professional work as drivers (bus, truck or car) with contraband activities, often delivering the smuggled fuel to specific addresses (e.g., petrol stations or shops) in Peru for further sale. Some drivers practice acopio de combustible, gathering fuels little by little before transporting them across the border. In the smaller villages close to the border, there are casa de acopio, houses where people stockpile fuel before taking it across the border by night. Some cars have a double tank, or falso piso. Large-scale fuel smuggling also takes place by night in trucks travelling in rows referred to as culebra or serpiente (snake), sometimes bringing goods from the border areas all the way to Cuzco. These trucks are said to leave behind sacks of food or other goods in local communities along the way in return for help in realising the smuggling. Several interlocutors said that the trucks also pass without interference by leaving bags of money at local police stations.

The towns of Desaguadero and Puno are important locations for the transport and sale of illegally imported fuel in Peru. In both towns, the fuel has at times been sold quite openly on the streets, while in cities like Arequipa sales have been more covert. Desaguadero is located at the border between Peru and Bolivia; here one officially crosses the border at a bridge where people pass either on foot or by bicycle trolley. Those who have larger loads pass by boat a distance away from the bridge. In the area around the bridge, there are people who, for around two soles, will transport people's goods across the border. Referred to in the media as pulgas or hormigas (lice or ants), these couriers may pass the border many times to bring a customer's merchandise across. People come to Desaguadero 
from across Southern Peru to buy contraband goods, including fuel. To pass the border with their goods, people commonly pay coima (a bribe) to the custom officials (generally 2-3 soles to enter Bolivia, and 10-20 soles on the way back). For a time from 2009 onwards, one of my interlocutors, Olinda, earned a living by bringing fuel from Bolivia, often travelling by bus and placing her goods on the roof hidden underneath other packages. She brought about 50 gallons at a time to sell to petrol stations in Puno where the smuggled fuel was usually mixed with ordinary products. Olinda made her initial investment with the help of her husband, who is a driver and could facilitate free transport. To live closer to the border and have a place for her goods, she rented a room from a relative in Yungoyo, ${ }^{12}$ a peasant community close to the border. Olinda is originally from Arapa, and the couple's three children have stayed behind in the village with their elderly grandmother, living under extremely poor conditions while their parents have been working. One day, just before I reached Arequipa in 2011 , Olinda was caught with fuels worth 10,000 soles. All of her goods were confiscated, and she had to pay 3000 soles to the custom officials (in bribes, not in fines) before the bus could pass. As we talked one day about the incident while sitting at her sister's market pitch at Mercado Nuevo, Olinda stressed how much she had suffered and cried after she was caught and lost her capital. She soon reestablished her business through the help of her kin, but decided not to include fuels. Although she had been rather successful and her earnings had been converted into the construction of a modern house (of brick and cement with glass windows) back in Arapa as well as education for her children at a private school in Arequipa, she now started to bring olives and clothes instead of fuels. 'You win and you lose, but you just have to continue', Olinda said. This is typical for contrabandistas' narrations about the risks that their businesses involve, stressing how they cry and suffer when their goods are confiscated-but also how they start up anew after a short time, still within the contraband trade, although sometimes downsizing quantities, or switching to another commodity. Olinda's narration indicates how contrabandistas spend their earnings for the benefit of their family and relations. While these earnings originate in illegal economic activities that challenge state-corporate interests and investments, the profits are sometimes spent in accordance with an urban middle-class life standard ideal (such as, in the case of Olinda, on a modern house and education), in addition to gifts, offerings and other 'relational' expenditure, as I illustrate below. 


\section{Prosperous Socialities}

Smuggling takes place in areas considered as tierras de nadie (no man's land), referring to places characterised by a history of marginalisation, a strong sense of local autonomy, and the ambiguous presence of state actors. These are areas where trade is already institutionalised in the absence of state control. The social and spatial embeddedness of trade is central to the practices of smuggling, which are based in networks of cooperation through household and kinship relationships that span from rural to urban areas. These relationships along trading routes may provide, for example, information and supply or storage of goods (see also Smith 1989; Babb 2001; Seligmann 2001; McNeish 2001; Ødegaard 2008, 2016). Success in the contraband business depends on relationships of trust, cooperation, and mutual exchange. Contrabandistas and vendors cultivate social relations assiduously through the sharing and giving of food and gifts, by establishing familial connections through godparenthood, and by maintaining often relatively stable relationships with customers and suppliers. Social relations thus enable the distribution of goods, including fuel, beyond authorised infrastructures and institutions.

More often than not, public functionaries are willing to receive bribes in exchange for their non-interference and to let people pass with their goods. In this way, the relational character of trade seems to constitute a means by which state officials at different levels can make money from the extralegal activities of contrabandistas. These exchanges are called bribes (coima) and not gifts, although contrabandistas often draw a parallel between coima and gift and view it as lack of respect when public functionaries refuse to accept a coima. As I explore below, similar dynamics of mediation and exchange take place in contrabandista relations with earth-beings. Powerful surroundings and apus (mountain lords), like the public functionaries, must be appeased through gifts or offerings to ensure, among other things, the circulation of merchandise. Comparable strategies - gifts, offerings, bribesare thus called for in dealings with representatives of the state as with the earth-beings to ensure control of commodity flows. Krøijer (this volume) discusses a different yet related situation among the Secoya in Peru. According to oil's essential leakiness, the Secoya establish an analogous relationship between oil, blood, and other (unintended) flows to deal with the oil present in their territory: a substance that if not contained and handled correctly might disturb the healthy flow between body and territory and powerful 'others'. In the case of the contrabandistas, they work primarily to 
redirect the flow of fossil fuels and the associated wealth, and to do so require mediation of and by other powerful substances and entities.

Interregional trade and barter have been essential to people in the Andes for centuries (Murra 1980; Platt 1982; Larson and Harris 1995). In the Southern Andes, contemporary cross-border trade follows the same routes used during the colonial period along which mule drivers transported goods between highland towns, such as La Paz, Puno, and Arequipa as well as towns along the Pacific coast, to Chile. While building on a long-standing history of barter and trade, interregional trade increased significantly during the 1980s-90s in both rural and urban areas (Smith 1989; Babb 2001; Seligmann 2001; Montesinos 2007, 2011; Tassi et al. 2013). In reaction to labour surplus and rising unemployment caused by structural adjustment programmes imposed by the IMF-implying privatisation and a reduction of the public sector-people increasingly turned to cross-border trade and market work, particularly during the economic downturn of the 1980s. Then as now, this work often takes place at the margins of the formal economy and builds upon social structures that have facilitated access to the market on the vendors' own terms (see Larson and Harris 1995; Arnold and Spedding 2009; Tassi et al. 2013). Against this backdrop, it could be tempting to interpret the practices of contrabandistas as a response to socio-economic processes and inequality, or as a form of non-hegemonic globalisation 'from below' (see Lins Ribeiro 2009) similar to the development of informal economies taking place worldwide. Such a focus would, however, emphasise mainly the economic nature of the contrabandistas' activities and could lead us to reduce their practices to a question of economic positioning. It could lead us to ignore important historical continuities of relational economics in the Andes and undermine ethnographic specificities by downplaying difference and ways of 'conceptualising otherwise' among contrabandistas, that is, conceptualising that departs from the Euro-American. Despite their strong Aymara and Quechua origins, the contrabandistas have usually been addressed by ethnographies more interested in economic 'informality' in South America (Goldstein 2016) than in Amerindian worldviews. In contrast, this chapter considers that the contrabandistas' redirection of commodity flows from official distribution entails a subsumption of wealth to modes of sociality and relationships that differ from the dominant forms. In an attempt to rethink a critical anthropological politics informed by the so-called ontological turn, Hage (2012) argues for the need to explore precisely the ontological underpinnings of relations of inequality. According to Hage, a social relation can always be understood 
in more than one way; that is, a social relation is always more than a 'relation of power', a 'relation of domination', or a 'relation of exploitation' (2012: 306). While we can recognise a social relation as a relation of power and dominance that reproduces a certain order of things, drawing on critical sociology, we should recognise the potential also for radical alterity-that there may be 'an outside of a system of intelligibility, of governmentality, of domestication, of instrumental reason' (ibid.: 306). This, I find, is a relevant point for the case of the contrabandistas; while their relations are certainly ones of historically conditioned inequality and marginalisation (i.e., relatively poor people with an indigenous background), we need to reveal also the relations of difference and translation that are likewise at stake.

By redirecting global commodities into informal circuits of exchange and distribution, contrabandistas profit, and, simultaneously, subsume profit to particular modes of sociality that rely on mutual exchange and gift giving (see also Gandolfo 2013). The wealth of an extractivist economy is, in this manner, translated to another set of distributive relations, where wealth is circulated and distributed in different ways and has the potential to create other sets of relations (although the accumulation of wealth is not avoided altogether, as is discussed below). Rather than representing a mode on which official commodity chains of capitalism depend, however, such as the pericapitalist mode outlined by Tsing, the informal circuits of contrabando divert and multiply the forms that extractive wealth may take. Instead of contributing to capitalist accumulation as discussed by Tsing then (and pinpointed by Harvey's (2007) term 'accumulation by dispossession'), this unofficial mode of translation can be termed accumulation by diversion, representing a mode by which wealth is partly subsumed and converted to a different form and enter different relationships. This conversion or translation is not only economic in nature; global commodities and flows are integrated into other relations and other sets of symbolic meaning. The translation and redistribution therefore entails a semiotic multiplication too, as wealth is translated to another set of relationships and meaning, escaping (partly) capitalism's system of commensuration and elite accumulation. We could view this as a relation of partial connection. According to Strathern (2004), the relation between dissimilar domains can only ever be as partial connections, by which a relationship composes an aggregate that is 'neither singular nor plural, neither one nor many, a circuit of connections rather than joint parts' (2004: 54). As I illustrate in the following, a central dimension to contrabandistas' acts of conversion and translation are their relations to earth-beings as powerful sources of wealth as well as danger. 


\section{Mobility, Wealth, and Translations OF THE EXTRALOCAL}

Many contrabandistas perform offerings to both powerful earth-beings and saints as a way of maintaining good relations with the sources of wellbeing and wealth and to improve success in business. The making of offerings is among the practices that characterise a relationship with the powerful Andean landscape (see also Allen 1988; Lund Skar 1994; Harris 1995; Canessa 2000; de la Cadena 2010; Ødegaard 2008, 2011) and reflects a particular cosmology of place where earth-beings are considered to have a powerful influence over the lives of humans with the potential for bringing prosperity as well as causing harm. Offerings consist of alcohol, food, llama fat, herbs, or coca and are made to pachamama (earth) and the apus (mountains), or to virgins or saints considered to be particularly prosperous and powerful. Large-scale contrabandistas and vendors are also expected to serve as sponsors for offerings, festivals, and parties, illustrating the significance of a relational understanding of wealth among contrabandistas as being dependent on reciprocity, circulation, and exchange between humans and earth beings (see also Harris 2000). Earth-beings represent an extrahuman prototype of 'other', whose power may be actualised in the form of health, income, and wealth, but also in the form of illness, accidents, and death. Sustained by the offerings, earth-beings depend on the same vital substances as humans do (alcohol, meat, fat, coca) and have similar needs and feelings. Along similar lines, although from a different perspective, Stensrud (this volume) illustrates how earth-beings in the Peruvian context are not necessarily deliberately (re)invented as part of an indigenous strategy to stop extractivism; rather, they are part of relationships continuously nurtured within on-going life projects (see Blaser 2004).

Deprived of offerings, the earth-beings may also attack human beings and cause illness and even death. The health and boundaries of the human body must therefore be maintained by making gifts and offerings to the earth-beings. Travellers, such as the contrabandistas, who voyage great distances are especially vulnerable. While contrabandistas tend to celebrate flow and mobility, which I discuss below, they are vulnerable not only to interfering state functionaries at border check points, but also to potentially malevolent earth-beings. Travellers need to protect themselves against powerful surroundings, by, for instance, making offerings or bringing stones, soil, or food from the place left behind. Movement through powerful surroundings, which are located and manifested in 
different local and regional landscapes, may disturb the flow of material exchanges and communication between a person and the surroundings, putting the traveller in danger (see also Allen 1988; Lund Skar 1994; $\varnothing$ degaard 2011). Danger can arise because the soil of a new place may not yet know you, a situation that can threaten one's health and general wellbeing. The notion that a place can know refers in this case to a way of knowing (someone or something) through the exchange of material substance: that is, you know someone based on what they give you. A traveller can achieve this knowing by bringing soil or a stone in a bag or pocket from their starting point or by making an offering. By bringing substances or objects from the place left behind to a new environment, the powers from the starting locale may mediate with the powers at a new place of arrival, enabling the traveller to reestablish a relationship with a powerful landscape. Although thus potentially dangerous, movement and circulation represent important cultural values in the Andes, as part and parcel of the reciprocal relationship between humans and earth-beings. In this regard, the general appreciation in this context of the often hard-working contrabandistas may illustrate Harris' (1995: 309) point that those who engage in trade in the Andes provide an important social service by bringing goods and making money 'give birth', hence ensuring material flows.

Material exchanges between humans and earth-beings rely on a notion of wealth that differs from the predominant, modernist vision in public discourse of progress and development, as, for instance, furthered by resource extraction and the perception of 'nature as object'. Commodification and monetisation of 'natural resources' enable a disconnection from place and a separation of subject and object-making nature a passive object from which humans can extract resources. The offerings made by contrabandistas entail ontological dynamics that provide a different understanding. Despite this and other ways of contravening the dominant form of capitalist accumulation and extraction, the political/symbolic economy of contrabandistas is simultaneously closely entangled with the extralocal (e.g., through the informalisation of global commodities). The social, economic, and ritual ways of contrabandistas can be seen as a practice aimed at the integration and translation of ambivalent extralocal value (see Orta 2004), and form part of an emphasis on harnessing value to create kinship; or familiarising predation in Fausto's terms (2007). Their practices turn on translating, incorporating and harnessing extralocal values to local ends, such as the use of global commodities for informal trade, 
sharing, and consumption. These practices are part of life-making projects that rely on forms of redirection or 'leakage' from official commodity circuits, and are in many ways complicit with capitalist extraction as the practitioners benefit, albeit to a limited extent, from the wealth produced. The perspective and mode of sociality of the contrabandistas differs from the dominant capitalist paradigm though, as their practices aim to recreate local forms of relatedness (see Penfield, this volume, for a similar argument). The relations that result can be seen as an aggregate of partial connections (Strathern 2004), creating not a single entity but an entity that is more than one yet less than two.

Contrabandistas are nevertheless receptive to dominant terms like those of progress and development and also speak in such terms-that is, by applying a notion of progress to their own lives as well as those of others. As Evangelina, one of my interlocutors, said about one of her more successful contrabandista colleagues, who has accumulated more wealth than many of her colleagues: 'She is really progresada. ${ }^{13}$ She carries dollars under her skirt (pollera), she has bought a big house in the city, and has even invested in a truck.' This allusion to wealth being 'carried under her skirts' is related to the notion that women in this part of the Andes are considered more likely than men at saving earnings and taking care of wealth and issues of reproduction (see Harris 2000). Interestingly, among contrabandistas, the truck occupies a central position in symbolic and economic elaborations of an idea about movement and circulation. For instance, at festivals organised by vendors and contrabandistas at Mercado Nuevo, miniature trucks figure in some dances, especially one in which women swirl colourful ropes with miniature ${ }^{14}$ trucks fastened to the ends. These women are usually dressed in polleras from Puno, generally of the most recent, colourful fashion and expressive of the successful and economically powerful Aymara entrepreneur. Vendors at the market also sell miniature trucks for offerings made in the hope of acquiring a real truck or other forms of wealth. The truck symbolises the work of contrabandistas and the flow and circulation of goods and money that they ensure. The truck also symbolises wealth and progress. As in the case of Evangelina's colleague, contrabandistas who succeed in their businesses often choose to invest in a truck for the purpose of continuing the practice that allowed them to acquire the truck-transporting contraband goods. 


\section{Conclusions}

By redirecting the official distribution of fossil fuels, contrabandistas subsume fossil wealth to other modes of sociality, for instance, by sharing and investing in colleagues, kin, and earth-beings. In this chapter, I have argued that contrabandistas can be viewed as translators from one form of value accumulation to another, not to the state or to the benefit of dominant firms as in the pericapitalist mode (Tsing 2015) but to forms of sociality and locality that to a great extent evade authorised institutions and infrastructures of distribution. While contrabandistas facilitate the circulation of global commodities, theirs is a different kind of life project (Blaser 2004) with a perspective and mode of sociality where flow is aimed at recreating local forms of relatedness.

Instead of contributing to capitalist accumulation in a conventional sense, the contrabandistas practice accumulation by diversion by which wealth is subsumed and converted to take different forms and enter different relationships. The translation and redistribution entail a semiotic multiplication as well, as wealth is translated to another system of meaning and (partly) escapes the capitalist system of commensuration. Their practices implicate and create social relations, including relations to the powerful earth-beings, and involve a relational understanding of wealth as dependent on reciprocity, circulation, and exchange. These practices rely on a notion of wealth that departs from the dominant, modernist vision expressed in public discourse of progress and development, as, for example, facilitated through resource extraction and the perception of 'nature as object'. The contrabandistas' redirections of commodities from official circuits are part of life-making projects that partly differ from and are partly complicit with hegemonic discourses on resource extraction and progress in that they are closely entangled with the translation and conversion of extralocal value. As a result, the practices of contrabandistas uncover the porous entanglements, or the partial connections, of locally embedded practices and the extractive politics of the state. Extractive capitalism in this context thus seems to coexist in partial connection with a radically different alternative.

While most studies of extractive conflicts in South America focus on groups who unambiguously resist the state's enforcement of extractive politics, I have revealed some of the tactics and concepts used to mediate these forces and the associated wealth (see also Krøijer, this volume, and Penfield, this volume, for related arguments). My focus on this redirection and possible translation of fossil wealth has not been intended to underplay, however, the issue of wealth accumulation and inequality in the 
extractive state. On the contrary, smuggling must be seen to emerge from relations of inequality, both historically and in view of contemporary extractive politics in Peru. Contrabandistas legitimate their practices with reference to conditions of inequality as well as contemporary price-setting mechanisms, and smuggling can be considered a way to mediate the forces of the state's extractive politics. Understanding these practices requires attention not only to commodity flows but also to the relational, cultural, and cosmological aspects, or logics, of mediation.

Acknowledgements My warmest thanks to people and friends in Peru who were so kind and helpful to let me follow them in their daily lives and who shared with me their experiences and points of view. Many thanks also to Juan Javier Rivera Andía for his constructive comments and to Katharine Wheeler and Isabelle Hugøy for their help with language editing; your assistance, advice and support is highly valued! I would also like to thank Casey High for his valuable suggestions based on an earlier version of this chapter, and to John McNeish and the project Contested Powers, for providing funding from the Research Council of Norway for some of my fieldwork. In addition, many thanks to Magaly Cardich for her research assistance during one of my fieldworks.

\section{Notes}

1. I use the term earth-entities to refer to nonhuman beings of the landscape, such as pachamama (earth) and apus (mountains) (see de la Cadena 2010, and Stensrud, this volume).

2. Names of interlocutors and places have been changed for purposes of anonymity.

3. Bolivia's prices were about one-third of prices in Peru.

4. Along Cuenca Suche, the river that goes through Desaguadero, there are a range of unauthorised mining businesses.

5. Peru Oil Exploration Set, 15 October 1971, https://www.nytimes. com/1971/10/15/archives/peru-oil-exploration-set.html, accessed 23 February 2017.

6. Henry Hub is a distribution hub on the natural gas pipeline system in Louisiana owned by Sabine Pipe Line LLC. The importance of this hub is reflected in the use of its name for the pricing point for natural gas future contracts that are traded on the New York Mercantile Exchange. In finance, such future contracts are legal agreements to buy or sell something at a specified time in the future at a predetermined price.

7. From 14 to 15 soles per gallon of gas, while other types of gas ( 95 per cent) rose to 20 soles. 
8. Also in July 2010, there were protests in Cuzco, Puno, Tacna, and Arequipa against the exportation of gas from Camisea.

9. Levantan provisionalmente huelga en Ucayali tras 11 días de manifestaciones, 19 March 2016. http://larepublica.pe/politica/749727-levantanprovisionalmente-huelga-en-ucayali-tras-11-dias-de-manifestaciones, accessed 23 February 2017.

10. This is from an interview which took place in Arequipa in 2011.

11. In 2011 , illegal export of fuels represented a loss of approximately US $\$ 450$ million for Bolivia (La Razón, La Paz, 27 January 2011).

12. I have changed the original names of these villages.

13. This is a neologism meaning that 'she has progressed'.

14. This use of miniatures is part of a wider practice in the Southern Andes referred to as las alasitas.

\section{REFERENCES}

Allen, Catherine. 1988. The Hold Life Has. Coca and Cultural Identity in an Andean Community. Washington/London: Smithsonian Institution Press.

Arnold, Denise, and Alison Spedding. 2009. La region altiplano como espacio económico. In Altiplano, ed. Denise Arnold. La Paz: UNIR.

Babb, Florence. 2001. Market/Places as Gendered Spaces: Market/Women's Studies over Two Decades. In Women Merchants in Cross-Cultural Perspective: Mediating Identities, Marketing Wares, ed. L. Seligman. Redwood City: Stanford University Press.

Blaser, Mario. 2004. Life Projects: Indigenous People's Agency and Development. In In the Way of Development. Indigenous Peoples, Life Projects and Globalization, ed. Mario Blaser, Harvey A. Feit, and Glenn McRae. London: Zed Books.

Canessa, Andrew. 2000. Fear and Loathing on the Kharisiri Trail: Alterity and Identity in the Andes. Journal of the Royal Anthropological Institute 6: 705-720.

de la Cadena, Marisol. 2010. Indigenous Cosmopolitics in the Andes: Conceptual Reflections Beyond "Politics". Cultural Anthropology 25 (2): 334-370.

Fabricant, Nicole. 2013. Good Living for Whom? Bolivia's Climate Justice Movement and the Limitations of Indigenous Cosmovisions. Latin American and Caribbean Ethnic Studies, Special Issue: The Politics of Indigeneity in Bolivia 8 (2): 159-178.

Fausto, Carlos. 2007. Feasting on People: Cannibalism and Commensality in Amazonia. Current Anthropology 28 (4): 497-530.

Gandolfo, Daniella. 2013. Formless: A Day at Lima's Office of Formalization. Cultural Anthropology 28 (2): 278-298.

Gibson-Graham, J.K. 2006. A Postcapitalist Politics. Minneapolis: University of Minnesota Press. 
Goldstein, Daniel M. 2016. Owners of the Sidewalk: Security and Survival in the Informal City. Durham/London: Duke University Press.

Hage, Ghassan. 2012. Critical Anthropological Thought and the Radical Political Imaginary Today. Critique of Anthropology 32 (3): 285-308.

Hardt, Michael, and Antonio Negri. 2000. Empire. Cambridge, MA: Harvard University Press.

Harris, Olivia. 1995. The Sources and Meanings of Money: Beyond the Market Paradigm in an Ayllu of Northern Potosi. In Ethnicity, Markets and Migration in the Andes. At the Crossroads of History and Anthropology, ed. Brooke Larson and Olivia Harris. Durham: Duke University Press.

- 2000. To Make the Earth Bear Fruit: Ethnographic Essays on Fertility, Work and Gender in Highland Bolivia. London: Institute of Latin American Studies.

Harvey, David. 2007. Neoliberalism as Creative Destruction. Annals of the American Academy of Political and Social Science 610 (1): 21-44.

Hobsbawm, Eric. 1969. Bandits. London: Delacorte Press.

Larson, Brooke, and Olivia Harris, eds. 1995. Ethnicity, Markets and Migration in the Andes: At the Crossroads of History and Anthropology. Durham: Duke University Press.

Li, Fabiana. 2015. Unearthing Conflict: Corporate Mining, Activism, and Expertise in Peru. Durham: Duke University Press.

Lins Ribeiro, Gustavo. 2009. Non-hegemonic Globalizations. Alternative Transnational Processes and Agents. Anthropological Theory 9 (3): 1-33.

Lund Skar, Sarah. 1994. Worlds Together, Lives Apart: Quechua Colonization in Jungle and City. Oslo: Scandinavian University Press.

McNeish, John. 2001. Pueblo Chico, Infierno Grande. Globalisation and the Politics of Participation in Highland Bolivia. PhD dissertation, Goldsmiths College, University of London.

Mitchell, Timothy. 2011. Carbon Democracy. Political Power in the Age of Oil. London/Brooklyn: Verso.

Montesinos, Jorge. 2007. Across the Highland: Construction of Aymara Identity at the Chile-Bolivia Border: National Representations, Ethnic Categories, and Transborder Exchanges. San Diego: University of California.

- 2011. Comerciantes Aymaras y circuitos transfronterizos en Bolivia y Chile. Paper presented at ERIP/CILAS/LACES conference, San Diego.

Murra, John Victor. 1980. The Economic Organization of the Inca State. Greenwich: Jai Press.

Ødegaard, Cecilie Vindal. 2008. Informal Trade, Contrabando and Prosperous Socialities in Arequipa, Peru. Ethnos. Journal of Social Anthropology 73 (2): 241-267.

. 2011. Sources of Danger and Prosperity: Mobility and Powerful Surroundings in the Andes. Journal of the Royal Anthropological Institute (formerly $M A N)$ 17: 339-355. 
2015. Everything Moves with Fuel. Energy Politics and the Smuggling of Energy Resources. In Contested Powers: The Politics of Energy and Development in Latin America, ed. John McNeish, Axel Borchrevink, and Owen Logan. London: Zed Books.

- 2016. Border Multiplicities. At the Crossroads between Regulation and Improvisation in the Andes. Journal of Borderlands Studies 31 (1): 23-38.

Ong, Aihwa. 2006. Neoliberalism as Exception: Mutations in Citizenship and Sovereignty. Durham: Duke University Press.

Orta, Andrew. 2004. Catechizing Culture. Missionaries, Aymara and the "New Evangelization”. New York/Chichester: Columbia University Press.

Platt, Tristan. 1982. The Role of the Andean Ayllu in the Reproduction of the Petty Commodity Regime in Northern Potosií (Bolivia). In Ecology and Exchange in the Andes, ed. David Lehmann. Cambridge: Cambridge University Press.

Seligmann, Linda J. 2001. Peruvian Street Lives: Culture, Power, and Economy Among Market Women of Cuzco. Urbana: University of Illinois Press.

Smith, Gavin. 1989. Livelihood and Resistance: Peasants and the Politics of Land in Peru. Berkeley: University of California Press.

Strathern, Marilyn. 2004. Partial Connections. New York: AltaMira.

Tassi, Nico, Carmen Medeiros, Antonio Rodriguez-Carmona, and Giovanna Ferrufino. 2013. "Hacer plata sin plata". El desborde de los comerciantes populares en Bolivia. La Paz: Programa de Investigación Estratégica en Bolivia.

Tsing, Anna Lowenhaupt. 2015. The Mushroom at the End of the World. Princeton: Princeton University Press.

Yanagisako, Sylvia Junko. 2002. Producing Culture and Capital. Family Firms in Italy. Princeton: Princeton University Press.

Open Access This chapter is licensed under the terms of the Creative Commons Attribution 4.0 International License (http://creativecommons.org/licenses/ by $/ 4.0 /)$, which permits use, sharing, adaptation, distribution and reproduction in any medium or format, as long as you give appropriate credit to the original author(s) and the source, provide a link to the Creative Commons license and indicate if changes were made.

The images or other third party material in this chapter are included in the chapter's Creative Commons license, unless indicated otherwise in a credit line to the material. If material is not included in the chapter's Creative Commons license and your intended use is not permitted by statutory regulation or exceeds the permitted use, you will need to obtain permission directly from the copyright holder.

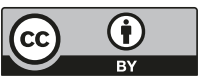

